\title{
Assembly of a ternary metallopeptide complex at specific DNA sites mediated by an AT-Hook adaptor
}

Soraya Learte-Aymamí, Jéssica Rodríguez, M. Eugenio Vázquez, and José L. Mascareñas

\section{Peer reviewed version}

This is the peer reviewed version of the following article: Learte-Aymamí, S.; Rodríguez, J.; Vázquez, M. E.; Mascareñas J. L. (2020), Assembly of a ternary metallopeptide complex at specific DNA sites mediated by an AT-Hook adaptor. Chem. Eur. J., 26: 8875-8878, which has been published in final form at https://doi.org/10.1002/chem.202001277. This article may be used for non-commercial purposes in accordance with Wiley Terms and Conditions for Use of Self-Archived Versions.

\section{How to cite:}

Learte-Aymamí, S.; Rodríguez, J.; Vázquez, M. E.; Mascareñas J. L. (2020), Assembly of a ternary metallopeptide complex at specific DNA sites mediated by an AT-Hook adaptor. Chem. Eur. J., 26: 8875-8878. doi: 10.1002/chem.202001277.

\section{Copyright information:}

(C) 2020 Wiley- $\mathrm{VCH}$. This article may be used for non-commercial purposes in accordance with Wiley Terms and Conditions for Use of Self-Archived Versions 


\title{
Assembly of a ternary metallopeptide complex at specific DNA sites mediated by an AT-Hook adaptor
}

\author{
Soraya Learte-Aymamí, ${ }^{[a]}$ Jéssica Rodríguez, ${ }^{[a]}$ M. Eugenio Vázquez, ${ }^{*,[a]}$ and José L. Mascareñas ${ }^{*,[a]}$
}

[a] S. Learte, Dr. J. Rodríguez, A/Prof. M. E. Vázquez*, Prof. J. L. Mascareñas

Centro Singular de Investigación en Química Biolóxica e Materiais Moleculares (CIQUS)

and Departamento de Química Orgánica, Universidade de Santiago de Compostela

15782 Santiago de Compostela (Spain).

Supporting information for this article is given via a link at the end of the document.

\begin{abstract}
We describe the nickel(II)-mediated self-assembly of a multimeric DNA binder composed by two metal-chelating peptides derived from a bZIP transcription factor (brHis 2 ) and one short AThook domain equipped with two bipyridine ligands $\left(\mathbf{H k B p y}_{2}\right)$. These peptides reversibly assemble in the presence of $\mathrm{Ni}(\mathrm{II})$ ions at selected DNA sequences of 13 base pairs.
\end{abstract}

Protein expression is mainly regulated at the transcription stage by the coordinated action of specialized proteins called transcription factors (TFs). ${ }^{1}$ Typically, TFs interact with specific DNA sequences as non-covalent homo- or hetero-oligomers, which ensures high affinity, while maximizing the number of accessible DNA sites through combinatorial targeting. ${ }^{2}$ Although a good number of synthetic DNA binders have been described in the literature, most of them are monomeric compounds or hybrids resulting from the covalent modification of DNA binding modules. ${ }^{3,4}$ However, the design of supramolecular DNA binders that exploit the self-assembly of different binding modules has been largely overlooked. In this context, we have explored the application of metal coordination as a potentially powerful approach to obtaining multimeric DNA binders. In particular, we have described a nickel-promoted DNA interaction of bipartite systems consisting of metal-chelating peptides and minor groove DNA binders equipped with bipyridine moieties. ${ }^{5}$ Herein, we demonstrate for the first time the viability of achieving a challenging tripartite DNA binding, involving the simultaneous formation of two metal coordination complexes. We report a Ni(II)dependent self-assembly of three peptides at DNA sites of up to $13 \mathrm{bp}$. A key element in our design is the use of an AT-hook peptidic domain equipped with two bipyridine chelating units. In the final complex, this hook is inserted in the minor groove at the center of the target DNA site, and recruits two bZIP basic regions to adjacent major grooves in response to the addition of $\mathrm{Ni}(\mathrm{II})$ complexes (Figure 1).

For our design, we selected as reference the bZIP yeast transcription factor GCN4, which specifically binds to the AP-1 (5'-ATGA(c)TCAT-3') or ATF/CREB (5'-ATGA(c/g)TCAT-3') sites as a leucine zipper-mediated dimer of $\alpha$-helices. ${ }^{6}$ The contacts with the DNA mainly take place through the $\mathrm{N}$-terminal basic region (br), which folds into the $\alpha$-helix upon binding to its target DNA sequence. ${ }^{7}$ Isolated basic regions show very weak affinities for the DNA, but we have shown that their covalent conjugation to an AT-Hook anchor can provide chimeric systems that fold and specifically bind with high affinity to composite sites containing the basic region target sequences. ${ }^{8}$ We now reasoned that equipping the AT-Hook with two bipyridine ligands (HkBpy2) might allow to recruit modified basic region peptides equipped with two His residues ( brHis $_{2}$ ) to adjacent DNA major grooves in response to a metal clip (Nickel(II), Figure 1). ${ }^{9}$ The Ni(II) mediates the self-assembly of the peptide binders and also acts as $\alpha$-helix nucleating agent. Interestingly, the whole supramolecular assembly would bind designed long $13 \mathrm{bp}$ sites with high selectivity.
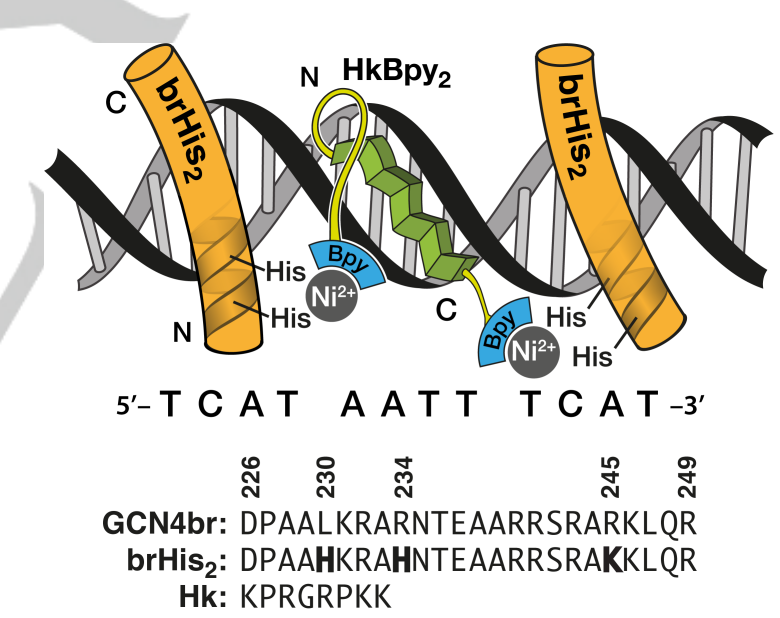

Figure 1. Top: Schematic structure of the supramolecular assembly of a bifunctional AT-Hook derivative equipped with bipyridine moieties $\left(\mathbf{H k B p y}_{2}\right)$ and two modified GCN4 basic regions (brHis 2 ). $\mathrm{His}^{230}$ and $\mathrm{His}^{234}$ residues coordinate $\mathrm{Ni}(\mathrm{II})$ and connect each of the two brHis 2 to the central AT-hook anchor. Bottom: Sequences of the natural GCN4 basic region and AT-hook peptides, as well as the brHis2. Mutated residues with respect to the natural GCN4 are in bold.

The peptide brHis 2 and the AT-Hook derivative HkBpy2 were synthesized following standard solid-phase peptide synthesis procedures. ${ }^{10}$ The $\mathrm{C}$-terminal bipyridine was derivatized as a Fmoc-protected amino acid with 5-amino-3-oxapentanoicacid (Fmoc-O1PenBpy-OH, 1, Scheme 1). ${ }^{11}$ The N-terminal bipyridine ligand was incorporated while the peptide was still attached to the solid support (Scheme 1). 


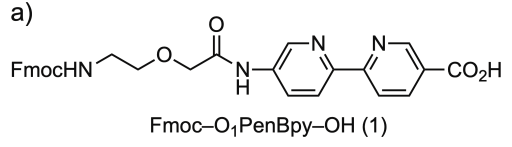

b)

1) $20 \%$ piperidine
DMF
2) Fmoc-O1PenBpy-OH
HBTU/HOBt
DIEA/DMF $\longrightarrow$ Fmoc-O ${ }_{1}$ PenBpy-

1) $20 \%$ piperidine DMF 2) Fmoc-aa-OH HBTU/HOBt $\left.\begin{array}{l}\text { DIEA/DMF } \\ 20 \% \text { piperidine }\end{array}\right\} \times 8$ $\mathrm{DMF}$

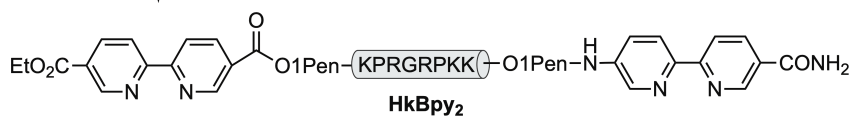

Scheme 1. a) Structure of Fmoc-01PenBpy-OH amino acid; b) Synthetic route to the AT-Hook derivative HkBpy2.

Having at hand the desired peptides, we studied their DNA binding properties by electrophoretic mobility assays (EMSA) in polyacrylamide gel under non-denaturing conditions, ${ }^{12}$ and staining the DNA with SYBR Gold. As expected, incubation of the peptide brHis 2 with the double-stranded (ds) oligonucleotide that contains the composite target site (TCAT- $\mathrm{A}_{2} \mathrm{~T}_{2}-\mathrm{TCAT}$ ), did not induce the formation of retarded bands in the gel (Figure 2a, lane 2). Addition of 20 equiv of $\mathrm{Ni}\left(\mathrm{ClO}_{4}\right)_{2}$ to this mixture did not generate new retarded bands (Figure $2 a$, lane 3 ), but subsequent addition of HkBpy2 gave rise to a new (more retarded) band that is consistent with the formation of the desired complex

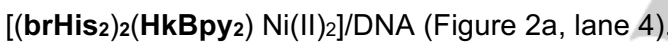

The EMSA conditions require the use of relatively large amounts of DNA and peptides, which induces some precipitation, and could also favor the kinetic disassembly of the complex. We therefore decided to quantify the interaction spectroscopically by running fluorescence anisotropy titrations. These experiments were carried out by adding increasing concentrations of the peptide $\mathrm{HkBpy}_{2}$ to a nanomolar solution containing a tetramethylrhodamine-labeled dsDNA with the target sequence, the peptide brHis, and $20 \mu \mathrm{M} \mathrm{Ni}\left(\mathrm{ClO}_{4}\right)_{2}$. As shown in Figure $2 \mathrm{~b}$, titration with $\mathrm{HkBpy}_{2}$ led to a progressive increase in the anisotropy, in agreement with the formation of a larger complex with decreased rotational diffusion. ${ }^{13}$ Considering a simplified 1:1 binding mode in which the $\left[\left(\mathbf{b r H i s}_{\mathbf{2}}\right)_{\mathbf{2}}\left(\mathbf{H k B p y}_{\mathbf{2}}\right) \mathrm{Ni}(\mathrm{II})_{2}\right]$ complex act as a single species binding to the DNA, we calculated an apparent dissociation constant of $22.3 \pm 0.4 \mathrm{nM}$ at $4{ }^{\circ} \mathrm{C}$. Taken together, these results confirm the need of the metal-chelating $\mathbf{H k B p y}_{2}$ anchor for the formation of the DNA peptide complex. Importantly, control experiments with AT-Hook derivatives featuring a single bipyridine unit, either $\mathrm{N}$-terminal $\left(\mathrm{Bpy}^{\mathrm{N}} \mathrm{Hk}\right)$ or $\mathrm{C}$-terminal $\left(\mathbf{H k B p y}^{\mathrm{C}}\right)$, did not produce slower-migrating bands under the same conditions in the presence of the target dsDNA (figure 2c). Additional control experiments with a basic region peptide containing a single His residue, confirmed that both histidines are required to detect any DNA binding (Figure S9). As expected, theAT-Hook peptide HkBpy2 by itself doesn't elicit new EMSA bands upon incubation with an oligo containing a target sequence $\mathrm{A}_{2} \mathrm{~T}_{2}$ (S12). ${ }^{14}$

The key role of the nickel ion in mediating the assembly of the supramolecular assembly led us to examine the possibility of dismantling the DNA complex by adding a competitive metal chelator. ${ }^{15}$ Gratifyingly, addition of EDTA to the mixture giving rise to the $\left[\left(\mathbf{b r H i s}_{2}\right)_{\mathbf{2}}\left(\mathbf{H k B p y}_{2}\right) \mathrm{Ni}\left(\mathrm{II}_{2}\right] / \mathrm{DNA}\right.$ complex, led to the disappearance of the slow migrating band in the gel, which is in agreement with the expected disassembly of the supramolecular DNA complex (Figure 2d). Additional studies demonstrated that the system assembles dynamically regardless of the order in which the components are mixed.
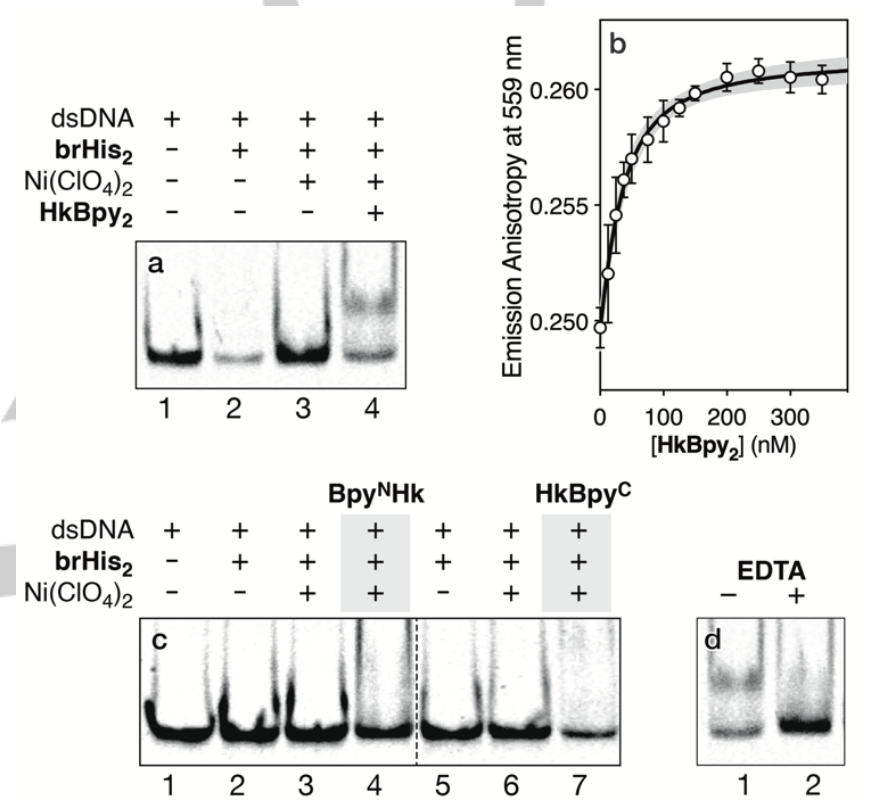

Figure 2. a) DNA binding studies for $\left[\left(\text { brHis }_{2}\right)_{2}\left(\mathbf{H k B p y}_{2}\right) \mathrm{Ni}(\mathrm{II})_{2}\right]$ with its target oligonucleotide (only one strand shown): 5'-GCGAG-TCAT-A $2 T_{2}$-TCATAGGCG-3'. Concentrations of the components are, when present: $75 \mathrm{nM}$ dsDNA, $2 \mu \mathrm{M}$ brHis $2,20 \mu \mathrm{M} \mathrm{Ni}\left(\mathrm{ClO}_{4}\right)_{2}$, and $1 \mu \mathrm{M}$ HkBpy $_{2}$. b) Fluorescence anisotropy titration at $559 \mathrm{~nm}$ of a $25 \mathrm{nM}$ solution of a tetramethylrhodaminelabeled ds-oligonucleotide (TMR-5'-GCGAG-TCAT-A 2 T2 $_{2}$-TCAT-AGGCG-3', only one strand shown) in the presence of $500 \mathrm{nM}$ of brHis $_{2}$ and $20 \mu \mathrm{M} \mathrm{Ni}\left(\mathrm{ClO}_{4}\right)_{2}$ with increasing concentrations of $\mathbf{H k B p y}_{2}$. The best fit to a 1:1 binding model is also shown. $95 \%$ confidence of the fit in light grey. Experimental data correspond to the mean of three independent titration experiments. All experiments carried out at $4^{\circ} \mathrm{C}$. c) EMSA of the $\mathrm{N}$-terminal $\left(\mathrm{Bpy}^{\mathrm{N}} \mathrm{Hk}\right.$ ) and C-terminal $\left(\mathrm{HkBpy}^{\mathrm{C}}\right)$ mono-bipyridine AT-Hook derivatives with the target oligonucleotide (lanes 4 and 7, respectively). d) EMSA of the complex [(brHis $\left.\left.)_{2}\left(\mathbf{H k B p y}_{2}\right) \mathrm{Ni}_{(\mathrm{II}}\right)_{2}\right]$ with its target oligonucleotide. Lane 1: $75 \mathrm{nM}$ dsDNA, $1 \mu \mathrm{M} \mathrm{HkBpy}, 20 \mu \mathrm{M} \mathrm{Ni}\left(\mathrm{ClO}_{4}\right)_{2}$, and $2 \mu \mathrm{M}$ brHis $_{2}$, lane 2: same mixture as in 1 after addition of 50 equiv of EDTA. EMSA experiments were resolved on a $10 \%$ nondenaturing polyacrylamide gel and $0.5 \mathrm{X}$ TBE buffer over $40 \mathrm{~min}$ at $4{ }^{\circ} \mathrm{C}$ and analyzed by staining with SYBR Gold ( $5 \mu \mathrm{L}$ in $50 \mathrm{~mL}$ of $1 X$ TBE) for $10 \mathrm{~min}$, followed by fluorescence visualization. Note: The slight smearing of the bands comes from the absence of EDTA, commonly used in these assays, and possibly also by the formation binary assemblies [( brHis $\left.\left._{2}\right)\left(\mathbf{H k B p y}_{2}\right) \mathrm{Ni}(\mathrm{II})\right]$ forming low-affinity complexes with the dsDNA.

We next studied the selectivity of the recognition process by using other dsDNAs with specific mutations. Not surprisingly, we did not observe the formation of retarded bands in the presence of mutated dsDNAs in both AP1hs target sites (ctctc- $\mathrm{A}_{2} \mathrm{~T}_{2}$-gagag, Figure $3 a$ ), or just in one of them (TCAT- $A_{2} T_{2}$-gagag, Figure $3 b$ ), which confirms the cooperativity of the coordination-mediated 
assembly. Furthermore, we did not observe the formation of retarded bands in the presence of a DNA lacking the A/T-rich tract required for AT-Hook binding, (TCAT-cagg-TCAT, Figure 3c). This result contrasts with previously studied ternary covalent derivatives that shows binding to the DNAs lacking the AT-rich tract, $^{8}$ and highlights the advantages of using non-covalent, dynamic supramolecular interactions to achieve high-affinity and selective DNA interactions. Not surprisingly, the flexibility of the supramolecular system allows some mobility in the minor groove, and thus tolerates a slightly larger $A / T$ spacer sequence between the basic region consensus sites $\left(\mathrm{TA}_{2} \mathrm{~T}_{2}\right)$, albeit the interaction in that case appears less intense.

\begin{tabular}{|c|c|c|c|}
\hline dsDNA & + & + & + \\
\hline brHis $_{2}$ & - & + & + \\
\hline $\mathrm{Ni}\left(\mathrm{ClO}_{4}\right)_{2}$ & - & - & + \\
\hline $\mathrm{HkBpy}_{2}$ & - & - & - \\
\hline
\end{tabular}

$\begin{array}{llll}+ & + & + & + \\ - & + & + & + \\ - & - & + & + \\ - & - & - & +\end{array}$
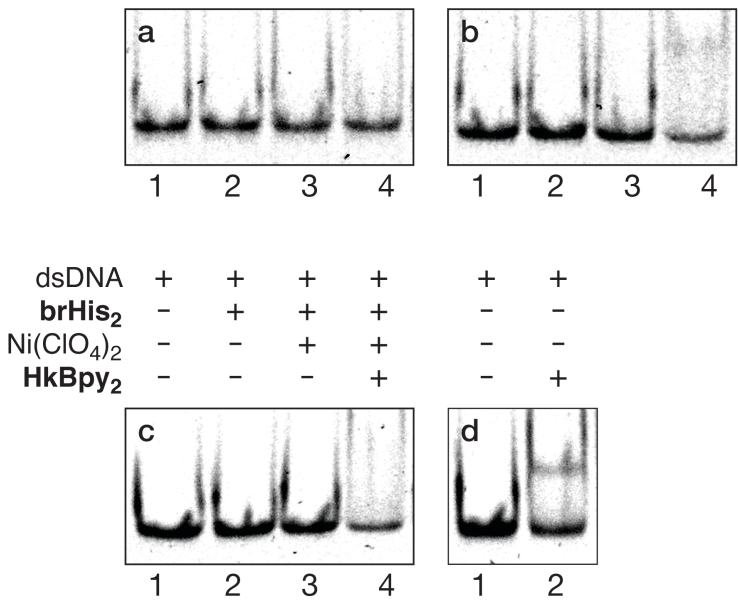

Figure 3. EMSA studies with $\left[\left(\mathbf{b r H i s}_{2}\right)_{2}\left(\mathrm{HkBpy}_{2}\right) \mathrm{Ni}(\mathrm{II})_{2}\right]$. Oligo sequences (only one strand shown): $\mathbf{a}$ : ctctc- $\mathrm{A}_{2} \mathrm{~T}_{2}$-gagag (both peptide sites mutated); $\mathbf{b}$ : TCAT$\mathrm{A}_{2} \mathrm{~T}_{2}$-gagag (only the binding site of one basic region mutated); $\mathrm{c}$ : TCAT-cagg-

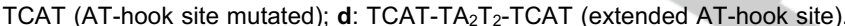
Concentrations of the components are, when present: $75 \mathrm{nM}$ dsDNA, $1 \mu \mathrm{M}$ HkBpy $_{2}, 2 \mu \mathrm{M}$ brHis 2 , and $20 \mu \mathrm{M} \mathrm{Ni}\left(\mathrm{ClO}_{4}\right)_{2}$. Experiment was resolved by PAGE on a $10 \%$ nondenaturing polyacrylamide gel and $0.5 \times$ TBE buffer over $40 \mathrm{~min}$ at $4{ }^{\circ} \mathrm{C}$ and analyzed by staining with SYBR Gold ( $5 \mu \mathrm{L}$ in $50 \mathrm{~mL}$ of $1 \mathrm{X}$ TBE) for $10 \mathrm{~min}$, followed by fluorescence visualization.

We also studied the selectivity of the system with regard to the metal ion ( $\mathrm{Co}(\mathrm{II}), \mathrm{Ni}(\mathrm{II}), \mathrm{Zn}(\mathrm{II}), \mathrm{Cu}(\mathrm{II})$, and $\mathrm{Fe}(\mathrm{II})$ salts). Using comparable conditions, we only observed the formation of more slowly migrating bands in the presence of $\mathrm{Ni}(\mathrm{II})$ cations (Figure S10). Therefore, it seems that nickel presents the best combination of properties-i.e., geometry, affinity and lability-to promote an effective trimeric assembly in the presence of the cognate DNA. ${ }^{16}$

As expected for a poorly structured peptide, the circular dichroism spectrum of brHis 2 presents a relatively weak negative signal at $222 \mathrm{~nm}$, even in the presence of HkBpy2 and the consensus DNA (Figure 4, solid line); the addition of $\mathrm{Ni}\left(\mathrm{ClO}_{4}\right)_{2}$ to the mixture promoted a considerable increase in the negative ellipticity intensity at $222 \mathrm{~nm}$, which is consistent with the folding of the peptide chain into an a-helix (Figure 4, thick line). ${ }^{17}$ In accordance with the results obtained by EMSA, the addition of EDTA to the supramolecular complex that resulted from mixing brHis $_{2}, \mathbf{H k B p y}_{2}$, the $\mathrm{Ni}(\mathrm{II})$ salt, and consensus DNA promoted a drastic decrease in the helicity of the peptide (Figure 4, dotted line), which correlates with the disruption of the DNA complex.

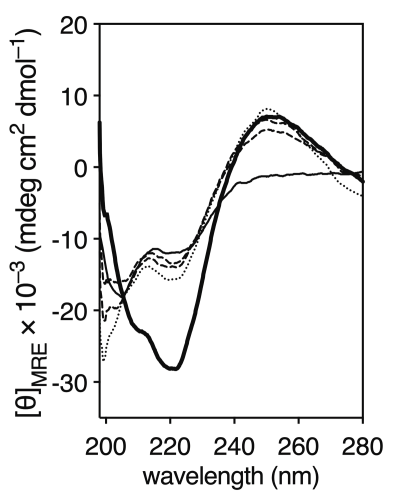

Figure 4. Circular dichroism of a $5 \mu \mathrm{M}$ solution of brHis 2 in $10 \mathrm{mM}$ phosphate buffer $\mathrm{pH} 7.5$ and $100 \mathrm{mM}$ of $\mathrm{NaCl}$ (solid line). Spectra after the subsequent addition of 1 equivalent of the target dsDNA and 1 equivalent of $\mathbf{H k B p y}_{2}$ (dashed lines), and after the addition of $\mathrm{Ni}\left(\mathrm{ClO}_{4}\right)_{2}$ (thick solid line). Addition of EDTA (dotted line) promotes the disassembly of the complex and demonstrates reversibility. The contribution of the DNA to the $C D$ spectrum have been subtracted for clarity and the MRE is calculated with respect to the 24-mer brHis. All experiments carried out at $4{ }^{\circ} \mathrm{C}$

Finally, we tested if the supramolecular complex could be assembled by an innocent linker that, unlike the AT-Hook, does not bind to the DNA minor groove. With this aim in mind we synthesized flexible oligoglycine and rigid oligoproline linkers equipped with the two bipyridines (Gly $7 \mathbf{B p y}_{2}$ and Pro $\mathbf{B}_{7} \mathrm{Bpy}_{2}$, respectively, see the Supporting Information). Both peptides are long enough to span the distance of approximately $32 \AA$ between the coordinating histidine residues in the two brHis 2 modules. Curiously, neither Gly7bpy2 nor Pro7bpy2 gave rise to stable peptide/DNA complexes upon incubation with DNAs containing composite consensus sequences (Figure S11). These results confirm that the AT-Hook is not a passive connector, but its interaction with the DNA and insertion in the $A / T$ rich minor groove are essential to obtain the desired peptide/DNA assembly.

In summary, we have introduced a new approach for achieving a highly selective trivalent recognition of specific, relatively long sequences of DNA. The recognition systems engages three individual peptide modules. Key for the success of the approach is the dual role of the metal as an a-helix-nucleating factor and heterodimerization clip. The multicomponent nature of the system and the kinetic lability of the metal coordination facilitate the disassembly of the supramolecular structure upon addition of external agents that sequester the nickel cation. The reported system features some of the emergent properties exhibited by naturally occurring DNA-binding proteins, such as multivalence, selectivity, responsiveness to external stimuli, and reversibility. The system represents an infrequent case of selfassembly, as it involves four different components: a metal, two peptides, and a nucleic acid.

\section{Acknowledgements}


Financial support from the Spanish grants SAF2016-76689-R, RTI2018-099877-B-I00, Orfeo-cinqa network CTQ2016-81797REDC, the Xunta de Galicia (2015-CP082, ED431C-2017/19 and Centro Singular de Investigación de Galicia accreditation 0192022, ED431G 2019/03), the European Union (European Regional Development Fund - ERDF), and the European Research Council (Advanced Grant No. 340055) are gratefully acknowledged. S. L.-A. thanks the Spanish MINECO for her FPI fellowship (BES-2017-080555); J. R. thanks the Xunta de Galicia

[1] C. W. Garvie, C. Wolberger, Mol. Cell 2001, 8, 937-946.

[2] a) H. C. Nelson, Curr. Opin. Genet. Dev. 1995, 5, 180-189; b) R. Moretti, A. Z. Ansari, Biochimie 2008, 90, 1015-1025; c) L. Chen, Curr. Opin. Struct. Biol. 1999, 9, 48-55.

[3] a) B. Cuenoud, A. Schepartz, Science 1993, 259, 510-513; b) C. R. Palmer, S. S. Sloan, J. C. Adrian, B. Cuenoud, D. N. Paolella, A Schepartz, J. Am. Chem. Soc, 1995, 117, 8899-8907; c) M. E. Vázquez, A. M. Caamaño, J. L. Mascareñas, Chem. Soc. Rev. 2003, 32, 338-349; d) E. Pazos, J. Mosquera, M. E. Vázquez, J. L. Mascareñas, ChemBioChem 2011, 12, 1958-1973; e) C. Y. Majmudar, A. K. Mapp Curr. Opin. Chem. Biol. 2005, 9, 467-474; f) M. E. Vazquez, A. M. Caamaño, J. Martinez-Costas, L. Castedo, J. L. Mascareñas, Angew. Chem. Int. Ed. 2001, 40, 4723-4725; g) O. Vazquez, M. E. Vazquez, J. B. Blanco-Canosa, L. Castedo, J. L. Mascareñas, Angew. Chem. Int. Ed. 2007, 46, 6886-6890; h) A. Iyer, D. Van Lysebetten, Y. Ruiz García, B. Louage, B. G. De Geest, A. Madder, Org. Biomol. Chem. 2015, 13 , 3856-3862; i) M. I. Sánchez, O. Vázquez, J. Martínez-Costas, M. E. Vázquez, J. L. Mascareñas, Chem. Sci. 2012, 3, 2383-2387; j) O Vazquez, M. I. Sánchez, J. Martínez-Costas, M. E. Vazquez, J.L. Mascareñas, Org. Lett. 2010, 12, 216-219

[4] a) M. Ueno, A. Murakami, K. Makino, T. Morii, J. Am. Chem. Soc. 1993, 115, 12575-12576; b) J. B. Blanco, V. I. Dodero, M. E. Vázquez, M. Mosquera, L. Castedo, J. L. Mascareñas, Angew. Chem. Int. Ed. 2006 118, 8390-8394.

[5] a) M. I. Sánchez, J. Mosquera, M. E. Vázquez, J. L. Mascareñas Angew. Chem. Int. Ed. 2014, 53, 9917-9921; b) S. Learte-Aymami, N. Curado, J. Rodríguez, M. E. Vázquez, J. L. Mascareñas, J. Am. Chem. Soc. 2017, 139, 16188-16193; c) J. Rodríguez, J. Mosquera, M. E. Vázquez, J. L. Mascareñas, Chem. Eur. J. 2016, 22, 13474-13477.

[6] a) P. Konig, T. J. Richmond, J. Mol. Biol., 1993, 233, 139-154; b) W. Keller, P. Konig, T. J. Richmond, J. Mol. Biol. 1995, 254, 657 - 667

[7] M. A. Weiss, T. Ellenberger, C. R. Wobbe, J. P. Lee, S. C. Harrison, K. Struhl, Nature 1990, 347, $575-578$.

[8] a) J. Rodríguez, J. Mosquera, J. R. Couceiro, M. E. Vázquez, J. L. Mascareñas, Chem. Sci. 2015, 6, 4767-4771; b) J. Rodríguez, J. Mosquera, R. García-Fandiño, M. E. Vázquez, J. L. Mascareñas, Chem. Sci. 2016, 7, 3298-3308; b) J. Rodríguez, S. Learte-Aymami, J. Mosquera, G. Celaya, D. Rodríguez-Larrea, M. E. Vázquez, J. L. Mascareñas, Chem. Sci. 2018, 9, 4118-4123.

[9] The design was based on the structures of the third AT-Hook of HMG-I(Y), bound to the IFN- $\beta$ promoter (PDB: $3 U X W)$, and the dimeric GCN4 DNA-binding domain bound to the AP1 ( $5^{\prime}$-ATGA(c)TCAT-3') site for her PhD fellowship. We also want to thank David Bouzada (CiQUS, USC) for sharing with us the bipyridine building block (Fmoc-O1PenBpy-OH, 1) used in the synthesis of the peptide HkBpy.

Keywords: peptides • DNA binding • supramolecular chemistry • molecular recognition $\cdot$ chemical biology

(PDB: 1YSA). Manual overlap of the DNA backbone in the complexes allowed us to construct a rough model of the simultaneous interaction of the AT-Hook and the two GCN4 peptides bound to contiguous sequences of the DNA. Inspection of this model suggested that $N$ - and $C$-terminal extension of the core AT-Hook sequence with 3-oxapentanoic acid units would allow crossing over the phosphate backbone.

[10] I. Coin, M. Beyermann, M. Bienert, Nat. Protoc. 2007, 2, 3247-3256.

[11] a) G. Rama, A. Ardá, J.-D. Maréchal, I. Gamba, H. Ishida, J. JiménezBarbero, M. E. Vazquez, M. Vázquez López, Chem. Eur. J. 2012, 18, 7030-7035; b) I. Gamba, G. Rama, E. Ortega-Carrasco, J. -D. Maréchal, J. Martinez-Costas, M. Eugenio Vázquez, M. V. López, Chem. Commun. 2014, 50, 11097-11100

[12] L. M. Hellman, M. G. Fried, Nat. Protoc. 2007, 2, 1849-1861.

[13] V. J. LiCata, A. J. Wowor, in Methods in Cell Biology, Academic Press, 2008, pp. 243-262.

[14] a) C. Crane-Robinson, A. I. Dragan, P. L. Privalov, Trends Biochem. Sci. 2006, 31, 547-552; b) L. Aravind, D. Landsman, Nucleic Acids Res. 1998 , 26, 4413-4421; c) R. Reeves M. S. Nissen, J. Biol. Chem. 1990, 265, 8573; d) T. Lund,K. H. Dahl, E. Mørk, J. Holtlund. S. G. Laland, Biochem. Biophys. Res. Commun. 1987, 146, 725-730.

[15] For other stimuli responsive-DNA binding tactics, see: a) A. M. Caamaño, M. E. Vázquez, J. Martínez-Costas, L.Castedo, J. L. Mascareñas, Angew. Chem. Int. Ed. 2000, 39, 3104-3107; b) A. Jiménez-Balsa, E. Pazos, B. Martínez-Albardonedo, J. L. Mascareñas, M. E. Vázquez, Angew. Chem. Int. Ed. 2012, 51, 8825-8829; c) J. Mosquera, M. I. Sánchez, J. L. Mascareñas, M. E. Vázquez, Chem. Commun. 2015, 51, 5501-5504; d) Y.Azuma, M. Imanishi, T. Yoshimura, T. Kawabata, S. Futaki, Angew. Chem. Int. Ed. 2009, 48, 6853-6856; e) A. Onoda, N. Arai, N. Shimazu, H. Yamamoto, T. Yamamura, T. J. Am. Chem. Soc. 2005, 127, 1653516540; f) J. Mosquera, A. Jiménez, V. I. Dodero, M. E. Vázquez, J. L. Mascareñas, Nat. Commun. 2013, 4, 1874-1881; g) C. Penas, M. I. Sánchez, J. Guerra-Varela, L. Sánchez, M. E. Vázquez, J. L. Mascareñas, ChemBioChem 2016, 1, 37-41; h) M. I. S.anchez, O. Vázquez, M. E. Vázquez, J. L. Mascareñas, Chem. Commun. 2011, 47, 11107-11109.

[16] For examples of nickel(II)-promoted biomolecular folding or assembly, see: a) R. J. Radford, F. A. Tezcan, J. Am. Chem. Soc. 2009, 131, 91369137; b) M. Kalek, A. S. Madsen, J. Wengel, J. Am. Chem. Soc. 2007, 129, 9392-9400; c) M. R. Ghadiri, C. Choi, J. Am. Chem. Soc. 1990, 112, 1630-1632.

[17[ J. T. Pelton, L. R. McLean, Anal. Biochem. 2000, 277, 167-176. 


\section{Entry for the Table of Contents}

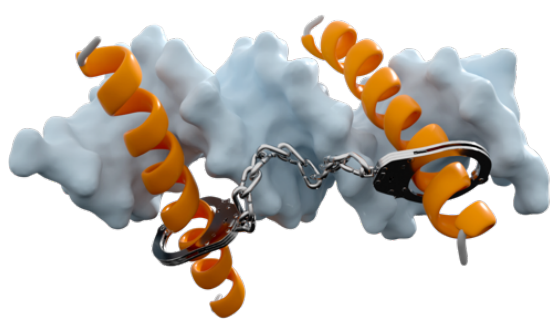

We demonstrate the selective recognition of specific DNA sequences by a designed supramolecular peptide assembly involving three peptide units. Metal coordination plays a dual role, bringing together the peptides as well as nucleating the DNA-binding $\alpha$-helices.

Institute and/or researcher Twitter usernames:

Soraya Learte-Aymamí: @sorayalearte M. Eugenio Vázquez: @ChemBioUSC José L. Mascareñas: @MetBioCat CiQUS: @ciqususc 